\title{
ROLE OF TRUST IN MEDIATING THE EFFECTS OF SATISFACTION AND COMMITMENT ON EMPLOYEE PERFORMANCE*
}

\author{
KIVANÇ İNELMEN** \\ Boğaziçi University
}

\begin{abstract}
This investigation was designed to study the relationships between the variables of satisfaction with extrinsic rewards, organizational commitment and trust perceptions of employees, and these variables' impacts on an organizationally important outcome, that is, performance. The data for this investigation comes from 230 service employees of 34 randomly selected quality restaurants in Istanbul. The analyses revealed that for service recovery performance prediction, the affective facet of commitment and the extrinsic reward facet of satisfaction have sizable influences as expected. However, the present results indicated that the determining factor of these variables relative to service recovery performance was the frontline employees' trust in their supervisor. Taken as a whole, the findings provided support for the proposition that employees' affective commitment and extrinsic reward satisfaction are necessary, but not sufficient by themselves without the mediating role of trust in the supervisor for predicting the frontline staff's service recovery performance. Finally, implications of the reported findings for the investigated quality restaurant businesses as well as other service sector firms are discussed, along with suggestions regarding the human resource practices offered to boost trust among employees.
\end{abstract}

Key words: trust in supervisor, extrinsic reward satisfaction, affective commitment, frontline employees.

\section{GÜVENIN, ISS TATMINI VE BAĞLILIK ÜZERINDEKI DOLAYLI ETKILLERI YOLUYLA ISSGÖREN PERFORMANSININ ŞEKILLENMESINDEKI ROLÜ}

$\ddot{O Z Z T T}$

Bu araştırmada, işgörenlerin dışsalödüllerden duydukları tatmin, örgüt bağlllıkları ve güven algılarının ilişkisi ile bu değişkenlerin çalışma örgütleri açısından önemli bir sonuç olan performans üzerindeki etkilerinin araştırılması amaçlanmıştır. Araştırmaya dâhil edilen veriler, İstanbul'dakiler arasından tesadüfì olarak belirlenmiş 34 lüks restoranda çalışan, 230 servis işgöreninden toplanmıştır. Yapılan analizler, servis hatalarını telafi performansının tahmininde, örgüt bağlılı̆̆ının duygusal boyutunun ve iş tatminin dışsal ödül boyutunun beklendiğ $i$ şekilde hatırı sayılır etkilerinin olduğu yönündedir. Ancak, bu araştırmada ortaya konulan sonuçlar söz konusu değişkenlerle, servis hatalarını telafi

* This study is funded by Bogazici University Research Grant \# B.A.P. 08N101.

** Kıvanç İnelmen is an Assistant Professor in the Department of Tourism Administration at Boğaziçi University, Hisar Campus, 34342, Bebek, Istanbul Turkey, E-mail: inelmenk@boun.edu.tr 
performansının ilişkisinde belirleyici öğenin, önsaha çalışanlarının yöneticilerine duydukları güven olduğunu göstermektedir. Bir bütün olarak ele alındı̆̆ında, elde edilen veriler işgörenlerin duygusal bağllklarının ve dişsal ödüllerle tatminlerinin gerekli, fakat tek başına yeterli olmayıp, ancak yöneticiye duyulan güvenin dolaylı etkisi yolu ile servis hataların telafisi performansinın tahmin edilmesine olanak verdiği yönündeki önermeyi destekler niteliktedir. Elde edilen sonuçların incelenen lüks restoran işletmeleri kadar, diğer servis sektörü firmalar bağlaminda ne anlama geldiğinin tartışılmasına ek olarak, işgörenler arasında güvenin arttırılmasına dönük olarak insan kaynakları uygulamaları alanında yapılabileceklere dair öneriler sunulmuştur.

Anahtar kelimeler: yöneticiye (üst amire) güven, dışsal öddül tatmini, duygusal bağllllk, önsaha işgörenleri.

Research in the organizational behavior field has largely been concentrated on supervisory work and on improving proficiencies of managers in corporations. Hofstede (2006) holds that this focus on managers, but not on people who actually do the work, is an outgrowth of U.S. management theories in this field. In the same vein, most studies of hospitality firms examine the employees holding managerial positions (Hancer and George, 2003) although the large majority of the employees and especially those who play the boundary spanning roles in touristic establishments are non-managerial employees. The importance of boundary spanning roles of frontline employees for securing customer satisfaction with the services rendered was established by numerous researches (e.g., Babakus et al., 2003; Bernhardt et al., 2000). Research conducted exclusively in food and beverage $(F \& B)$ establishments show that restaurants were no exception and customer satisfaction was closely related to the attentiveness of employees as much as to the consistency of the food (Bernhardt et al., 2000). Following this line of research, it could be concluded that the service personnel's interaction with customers in quality restaurants has been regarded at least as important as the culinary capability of the kitchen personnel. The present study investigated the relationships of the affective facet of organizational commitment, the motivation capacity of extrinsic rewards, and the employees' trust in their immediate supervisor in quality restaurants. It was proposed that the connections of these variables have a substantial impact on the non-managerial employees' performance. Because the impact of employee attitudes is more pronounced on organizational performance in restaurants compared to many other industries, these enterprises were suggested to be an ideal environment to test the effects of trust on performance (Davis et al., 2000).

\section{CONCEPTUAL BACKGROUND AND HYPOTHESES}

Quality restaurants are establishments whose sole business is to offer very high standards in all aspects of their operation - personalized service, an expensive a la carte menu, silver service, good quality facilities and décor, etc. Personalized or 'aided' service indicates that quality restaurants provide the transportation and service of food to the customer rather than requiring the customers to collect their own food (Davis B. et al., 2003). Recently, Wu et al. (2009) could empirically show that, compared to the restaurant environment or interactions with other customers, the interactions with service employees carry much larger weight in customer satisfaction. Moreover, in quality restaurants, the personalized service, i.e. detailed service planning and if necessary all potential problems being taken care of by the wait-staff, has been perceived to be an integral part of the customers' experience. Therefore, the service recovery function can be regarded as an important aspect of the performance of the personnel in quality restaurants. Parallel to Boshoff and Allen (2000), the service recovery performance is defined here as a non-managerial employee's self rating about his/her abilities to resolve a service failure and to return the dissatisfied customers to complete satisfaction. 
The high expectations of quality restaurant customers constitute both a concomitant challenge and an opportunity for these businesses. Such customer expectations require a matching level of employee performance that would be difficult to achieve without the wait-staffs' positive work attitudes (Davis et al., 2000). These optimistic attitudes on the part of the employees could be secured in part by achieving a high commitment to and a satisfaction with the establishment, and an accompanying willingness to actively resolve any service failures that could reduce the customer satisfaction (Babakus et al., 2003). This type of willingness, namely to engage in service recovery when needed, generally regarded as an important aspect of frontline performance in quality restaurants, demands well coordinated team work among personnel at all levels. Correspondingly, an atmosphere of trust between supervisors and subordinates has been deemed necessary in teamwork settings (Nyhan, 1999). The expected level of performance could only be secured by frontline employees having a positive work attitude and a confidence in the organization being interested in his or her welfare. The present study was designed to investigate the potential strength of the employees' trust in their supervisor as a mediating factor on their perceptions regarding the extrinsic reward satisfaction and affective commitment being the primary determinants for predicting frontline employee performance as suggested by Babakus and colleagues (2003). It is proposed here that without trust or " $\ldots$ the intention to accept vulnerability based on positive expectations" from their supervisors, (Rousseau et al., 1998: 395) neither affective commitment nor extrinsic reward satisfaction can secure an organizationally desired level of frontline employee performance.

The performance in business settings has been studied extensively as a critical outcome variable, from various perspectives. Still, performance could be regarded as an illusive topic, because depending on the type of research conducted, it can take different shapes such as organizational outcomes based on performance (Siders et al., 2001), customer satisfaction as an indicator of performance (Tax et al., 1998), self-rated performance compared to other group members (Baba et al., 2009), or supervisor ratings of performance (Meyer et al., 2002). In the hospitality context, a critical determinant of performance has been that of resolving service failure to the satisfaction of the customer in a short time span. Therefore, as suggested by Babakus et al. (2003), it could be argued that in the service sectors one of the most vital performance types from a managerial perspective is service recovery performance. In fact, the final consumer of services often experiences only a fraction of the service delivery process. However since even minimal problems in this encounter can lead to a reduced satisfaction on the part of the customer, both staff training and the assumption of initiative by this final service provider gain importance (Boshoff and Allen, 2000). It could be argued that the type of performance that is required by such businesses can only be achieved through corresponding levels of organizational commitment and reward satisfaction (e.g., Babakus, et al., 2002). However, when the task of the frontline employee requires going beyond the job description, the employees' trust in their supervisor in regard to the potential consequences of taking the initiative becomes a key element. Trust is an outgrowth of a party's willingness to be vulnerable to the actions of another party (Mayer et al., 1995), but if the risk of experiencing negative consequences for taking the initiative is high, it may be best not to act at all. Moreover, the history of the leader and the subordinate could also be expected to have repercussions on the subordinates' satisfaction with the outcomes and his/her organizational commitment (Meyer et al., 2001). Although satisfaction, commitment, trust and performance were commonly investigated topics, the interrelationships of these variables for the non-managerial restaurant employees have been rarely investigated (Hancer and George, 2003).

Job satisfaction has been a construct that was noted quite early by organizational behavior scholars as a key factor for business stability and long term success. Therefore, there is a long-standing tradition 
of investigating job related satisfaction (see Agho et al., 1993), which was deemed to have a great importance especially in the service sector, where the production and provision of service take place in the presence of customers. Their level of satisfaction is closely linked to the success of the establishment in delivering those services (Arnett et al., 2002). The most general, yet comprehensive, categorization for job satisfaction would be to view it either intrinsically oriented, i.e. derived from internally mediated rewards such as opportunities for personal growth and accomplishment, recognition, or, alternatively, to view it extrinsically, brought about by influences such as pay, benefits, awards, etc. The distinction of intrinsic and extrinsic influences in job satisfaction can be traced back to Herzberg's influential theory, which argues that motivators (or intrinsic factors) satisfy people's psychological needs such as getting recognition, carrying responsibilities and the like. Hygiene (or extrinsic factors) including compensation, working conditions and relationship with the supervisor, when lacking such could create dissatisfaction. Similarly, Bennett et al. (1994) found that employees with different levels of extrinsic reward satisfaction have the tendency to show attitudinal and behavioral differences. According to more recent reexaminations of job satisfaction, worker's satisfaction is affected by the expectation of rewards provided by the organization and the work environment. These rewards may be extrinsic or intrinsic, but "[w] hat is important is that the rewards an organization offers be tailored to the people they are trying to attract and keep" (Lawler, 2005: 13). In fact, Huang and Van de Vliert (2003) reported that extrinsic factors are strongly related to job satisfaction in the case of the frontline employees. Because turnover has long been a major problem in the hospitality sector in general, due to low wages, shift schedules and social perception about the job itself (Cho et al., 2009), one of the primary motives for working in quality restaurants for the frontline staff could be the appeal of extrinsic rewards attained in these enterprises.

Research in the hospitality sector showed that those employees with higher job satisfaction were more likely to deliver exceptional guest service (Arnett et al., 2002). Moreover, hotel employees were found to demonstrate higher levels of job satisfaction when they were more organizationally committed (Chen, 2007) and had pride in being a member of an organization (Arnett et al., 2002). It is not a coincidence that these variables are closely interrelated. Arnett and colleagues (2002) found that positive employee behavior was an outgrowth of job satisfaction and pride in organization variables for the hospitality sector workers. According to the same study results, the main antecedents of employee satisfaction were the evaluation of management, role clarity, work environment, and rewards systems. The evaluation of management construct, operationalized as recognizing employee needs (Arnett et al., 2002), could be regarded as a motivator in Herzberg's terminology. On the other hand, the rest of the antecedents, namely role clarity, work environment, and rewards systems, highlight the importance of extrinsic factors in job satisfaction. In fact, extrinsic factors were treated often independently from the intrinsic factors in the literature (e.g., Agho et al., 1993; Babakus et al., 2002; Hancer and George, 2003). Huang and Van de Vliert (2003) reported that extrinsic factors and relational factors (e.g., co-worker relationship) appeared to be even more strongly related to job satisfaction than intrinsic factors for the non-managerial employees in both individualistic and collectivistic nations. Moreover, extrinsic rewards besides being a common denominator for all employees, are among the less fulfilled antecedents of job satisfaction amongst wait-staff (Cho et al., 2009; Hancer and George, 2003); thus, they may allow more room for improvement in these establishments.

Another widely studied work attitude has been organizational commitment. The impact of organizational commitment on individual performance and organizational effectiveness has prompted much interest among researchers. For instance, Mowday et al. (1982) argued that organizational commitment has become a topic that is widely investigated in order to understand the employees' 
work-related behavior, because it was identified as more stable and less subject to daily fluctuations than job satisfaction. The attention in the construct is partly due to the construct's intuitive appeal as a factor affecting employee performance. It is also due partly to the great amount of research showing that organizational commitment does indeed influence several desired job outcomes including reduced absenteeism and turnover (Zeytinoğlu et al., 2006), self-reported citizenship (Meyer et al., 1993), job satisfaction (Wasti, 2003) as well as job performance (Meyer et al., 2002; Riketta, 2002). In a nut shell, according to Allen and Meyer (1990), positive work experiences lead to more organizational commitment, and the outcome of such commitment often is positive employee behavior.

Among the various ways of measuring organizational commitment construct in the literature, the two most commonly employed operationalizations were provided by Mowday et al. (1982) and Allen and Meyer (1990). Mowday and colleagues (1982: 27) defined organizational commitment as "the relative strength of an individual's identification with and involvement in an organization" and developed the Organizational Commitment Questionnaire (OCQ) with an attitudinal or affective attachment perspective. The second, but prevailing approach in the literature (Wasti, 2003), has been the Three Component Model of organizational commitment that provides a multidimensional conceptualization. Allen and Meyer (1990; Meyer and Allen, 1991) argued in their model that it is more appropriate to consider commitment as consisting of affective, continuance and normative components, since they develop somewhat independently as a function of different antecedents. They go on to argue that an employee's relationship with his/her firm might reflect varying degrees of all three. Although the multi-dimensionality of organizational commitment has found interest in the literature, how this dimensionality should be partitioned has not been among the topics researchers came to a consensus on to date. For instance, research found consistently that there is a strong positive correlation between affective and normative commitment, and Meyer et al. $(1993$; 2002) proposes that this relationship between the two dimensions can at least in part be explained by a common antecedent of positive work experiences, as well as by a similar positive association between normative and continuance commitment because of the correlates such as sense of obligation to others. Consequently, it could be argued that the common ground in Mowday et al. and Meyer et al.'s assessment of organizational commitment was the affective component, while in earlier research this component was used in isolation to measure organizational commitment (e.g., Babakus et al., 2002; Ertürk and Ceylan, 2002; Riketta, 2002).

As in the case of the earlier discussed constructs of extrinsic reward satisfaction and affective commitment, trust was regarded as an indispensable but complex phenomenon that needs to be reflected at different levels (Rousseau et al., 1998). Research on trust within business organizations has focused on several dimensions: interpersonal trust (e.g., Mayer et al., 1995), trust in top management (Whitener et al., 1998), trust in the immediate supervisor (e.g., Goris et al., 2003) and trust in the organization (e.g., Tan and Tan, 2000). It should be noted that recent research empirically established that trust in the supervisor and in the organization are distinct but related constructs. For example, in Tan and Tan's (2000) study, trust in the supervisor was found to be strongly correlated with the subordinate's satisfaction as well as with innovative behavior (defined as production or adoption and implementation of useful ideas), and whereas the trust in the organization was found to be more related to the organizational commitment and fewer intentions of leaving among service sector employees. Taken together, it could be stated that the widespread agreement on the importance of trust could not help to alleviate the lack of a common definition of the concept (e.g., Hosmer, 1995; Goris et al., 2003). Nevertheless, the potential gain for advancing knowledge on the trust construct was an enduring endeavor, since it was regarded to be a productive investigation area. 
In accordance with Blau's influential formulation, which highlighted the centrality of trust within social exchange relationships (Aryee et al., 2002), supervisor-employee dyads could be considered to be based on the perceived trustworthiness of each other. The overlap between the leader-member exchange theory (LMX) and the trust research suggests a fruitful integration for a better understanding of this dyadic relationship. Indeed, Brower and colleagues (2000: 229) stated that a “...high LMX relationship is characterized by mutual trust, loyalty, and behaviors that extend outside the employment contract." Service recovery performance, defined as abilities and actions to resolve service failure to the satisfaction of the customer, has clear inlays extending beyond the restrictions of basic job descriptions. Thought of with the prevalence of the job satisfaction and commitment constructs in the literature, one may be ready to accept that these two variables are possibly sufficient to secure the desired employee performance levels. But in the light of LMX theory, it could be argued that without an established trust of the leader, there is a high likelihood that an employee would be less willing to accommodate behavior that may not be directly described by his or her job description. Along the same lines, it could be suggested that frontline employees in the quality restaurant sector can also behave in a restricted manner if their supervisors do not demonstrate the basic requirements of trustworthiness, such as open communication, competence, integrity and consistency (Mayer et al., 1995), and thus employees may fail to provide the desired level of performance in the case of service failures.

In the quality restaurant industry, innovative behavior and initiative can be thought to have much common ground with service recovery performance. Thus, it could be suggested that the higher level of confidence in the supervisor can lead employees to become less risk averse and more inclined to intervene actively in service failures. Goris et al. (2003) concluded that the trust in the supervisor was substantially associated with both performance and satisfaction among industrial company employees as well. Similarly, Aryee et al. (2003) found that trust in the supervisor was a strong mediator for the employees' justice perceptions link with task performance, but they failed to replicate a similar result for job satisfaction. The above summarized research consistently points in the direction of employee satisfaction, commitment and performance all being highly interconnected with interpersonal trust, and it seems plausible to conclude that the relationship between these variables could be mediated by trust in the supervisor. However, there has been little, if any, attempt to tie trust in the supervisor with service recovery performance, particularly as a mediating variable. In an attempt to fill this void, this study aimed to provide information that could also be made use of by other service sector businesses.

\section{Hypotheses}

One of the objectives of the study was to investigate the impacts of two major antecedents, namely the employees' satisfaction with the extrinsic rewards and affective commitment in service recovery performance prediction. As discussed in the previous section, the extrinsic reward satisfaction could be regarded as a primary precursor of positive employee behavior (e.g., Agho et al., 1993; Arnett et al., 2002; Huang and Van de Vliert, 2003). Most of the recent empirical research provided support for its importance in predicting service recovery performance (e.g., Babakus et al., 2002), although there are some mixed conclusions regarding extrinsic factors being the major source of satisfaction in waitstaff performance (e.g., Hancer and George, 2003). To investigate this issue on a sample of frontline employees in the quality restaurant sector of Istanbul, the extrinsic reward satisfaction was included in the study framework as an independent variable for the prediction of service recovery performance. Thought of in this framework, extrinsic reward satisfaction could be expected to have a positive bond with service recovery performance. Consequently, the following hypothesis was forwarded: 
Hypothesis 1. Extrinsic reward satisfaction will positively predict service recovery performance.

For the purposes of the current study, the affective component of commitment was identified as one of the main determinants of service recovery performance (e.g., Babakus et al. 2000), and it was defined as the employees' emotional attachment to (almost personal identification with), and involvement in the organization, as it constituted a positive work attitude. Meyer and Allen (1991: 67) contend that "[e]mployees with a strong affective commitment continue employment with the organization because they want to do so", and thus such commitment could mean a robust intention to perform well within the organization. Relationship among affective commitment and performance has been investigated several times, and with various samples (e.g., Babakus et al., 2002; Meyer et al., 2002; Riketta, 2002). In most research conducted there was supporting evidence for a positive and strong bond between these two variables. However, a meta-analysis by Mathieu and Zajac (1990) showed that organizational commitment affects work performance only slightly in most instances. On the other hand, some research found a strong link between the affective commitment and the service recovery performance (Babakus et al., 2003). Therefore, the second hypothesis was formulated to investigate this link closely:

\section{Hypothesis 2. Affective commitment will positively predict service recovery performance.}

Looking at the picture that can be canvassed from earlier research, it could be suggested that there may be yet another variable that mediates the pooled effect of extrinsic reward satisfaction and affective commitment on service recovery performance. In this investigation, the trust in the supervisor was regarded as a candidate for providing this "missing link" in the above relationship. Following the widely employed trust definition of Mayer, Davis and Schoorman (1995), trust in the supervisor was defined here as the willingness of the subordinate to be vulnerable to the actions of his or her supervisor whose behavior and actions he or she could not control. This vulnerability stems from the risk or uncertainty regarding whether the other party intended to and would act appropriately. In the literature, the trust between the coworkers or in the supervisor-subordinate relationship was regarded as a valuable commodity that promoted the desired work outcomes (Goris et al., 2003). Fittingly, in a sample drawn from the hospitality industry, relationship with the supervisor -for that matter the trust and respect in the management- emerged as a substantial component of extrinsic job satisfaction (e.g., Chen, 2007). This result could be partly explained by satisfaction with externally mediated rewards such as pay, recognitions, awards, etc. being linked with trust in the supervisor in the eyes of the employees. In the same study, it was found that service orientation was positively correlated with organizational commitment due to job satisfaction. Research in hospitality settings showed that these antecedents were indeed highly correlated with trust in the supervisor (Inelmen, 2006), and it could mediate the relationship between organizational justice perceptions and organizational citizenship behavior (İşbaş1, 2001). In the same vein, Davis et al. (2000) found a significant positive relationship between the employees' trust in the general manager and the restaurant performance, and suggested that the trustworthiness of the manager is also crucial for enhancing individual subordinate performance.

Parallel to these findings, Aryee et al. (2002) found that trust in the supervisor mediates the relationship between interactional justice and task performance, and affective commitment was among the variables that related significantly to this performance. Similarly, Huang et al. (2010) found that trust in the supervisor mediated the participative leadership's effect on performance for 
non-managerial employees, whereas for managerial employees the mediation path was through psychological empowerment. Thought of in combination with Huang and Van de Vliert's (2003) conclusion that extrinsic rewards are more strongly related to job satisfaction in non-managerial employees than in managers, it could be argued that trust in the supervisor could be an outcome of extrinsic reward satisfaction for the present study's sample. Finally, Riketta's (2002) meta-analysis investigating the link between affective commitment and job performance hinted that the relationship between the supervisor and the subordinate might be one of the factors that had a substantial impact. Taken together, it could be concluded that trust in the supervisor was a major correlate of affective commitment, and thus it mediates the relationship between the employee's organizational commitment and performance. Therefore, as part of the pursuit of investigating this missing link, trust in the supervisor was regarded here as a core dimension for predicting service recovery performance, in the capacity of a mediating variable in relation to the study's independent variables. Thus the following hypothesis was put forward:

Hypothesis 3. The influences of extrinsic reward satisfaction and affective commitment on service recovery performance will be mediated by trust in the supervisor.

\section{METHODOLOGY}

\section{Sample}

The data was collected from in 34 quality restaurants. For the purposes of this study, the list of quality restaurants was obtained from the Ministry of Culture and Tourism, Istanbul Office. This list, which consisted of a total of 326 certified restaurants, was employed as the sampling frame of the study. Using the list that contains the addresses and telephones of the establishments, 10 percent of the restaurants (with enough substitutes) were selected randomly with the help of a computer program. The restaurants were then first grouped according to their geographic locations of the city's three main parts: Anatolian Side, European Side South (Old Town) and European Side North. To obtain a more balanced distribution of the selected restaurant in each part of the city, the list was reduced to include 31 independent quality restaurants. However, to provide a more complete picture of the industry, the inclusion of luxury hotel restaurant employees was also deemed necessary. The quality restaurants were mostly independently owned and operated, but Davis et al. (2003) contended that the luxury restaurants found in high-end hotels could be categorized as quality restaurants as well, because they shared similar characteristics with the former. Therefore, out of 32 five-star luxury hotels in Istanbul, three were randomly determined and survey questionnaires were also administered to employees in these hotels. All restaurants that were included in the study were initially contacted by telephone and, upon the consent received from the restaurant managers, project assistants delivered and collected the questionnaires.

Since the administration of the questionnaires required the volunteer contribution by the employees, at this stage the data collection had to rely on convenience sampling. The participants were assured about the confidentiality, and the use of the data only for research purposes. All together 239 completed questionnaires were returned, and after initial checks for consistency and statistical tests to secure normality and linearity of the study variables, 230 questionnaires were found usable and employed for all further statistical analyses. A vast majority of the respondents were male $(92.5 \%)$. Of the respondents, 58\% were between 18 and 28 years of age and $40 \%$ between 29 and 41, making the whole group's average age 28.15 years $($ S.D. $=2.93$ ). Thus most of the respondents were relatively young. Almost half of the respondents were married (46\%), and $71 \%$ had a high school or above education. 
For the above-described sample, the tenure in the current restaurant was on average 43 months $($ S.D. $=28.5)$ or approximately three and a half years.

\section{Measures}

All study constructs were measured with composite scales existing in the literature, with the exception of the Trust in Supervisor (TISU) scale. The TISU scale was developed by the present author in Turkish with an earlier study (İnelmen, 2006) and tested by an independent study (Göncü, 2006) that reported that the scale's psychometric properties were satisfactory. The original scale was composed of eight questions which were designed to assess the immediate supervisor's trustworthiness, positional power, fairness in performance evaluation, and protection and loyalty in the eye of the subordinate in hospitality settings (see Appendix A). In this investigation, the initial reliability analysis of the scale's Cronbach's alpha showed a moderately low result. Therefore, after the preliminary test which demonstrated the fifth item to have low inter-item correlations, this item was removed from all further analyses. This removal increased the reliability of TISU to 0.76 . Further, to assess the scale's new factor structure, a confirmatory factor analysis with principal axis factoring was conducted, which produced factor loadings that pointed to an acceptable fit $(\mathrm{KMO}=0.76$; Bartlett's Sphericity $=393.00$, $\mathrm{p}<.001$ ). For all composite scales in the employed questionnaire, responses to the statements were elicited on a 6 point Likert type span, ranging from 1 (strongly disagree) to 6 (strongly agree).

The originals of the Service Recovery Performance, and the Extrinsic Reward Satisfaction scales were in English. Therefore, these scales were first translated into Turkish by using a standard back-translation method. The cross-linguistic comparability of the questionnaire items were examined by four faculty members of a Turkish university who were fluent in both languages, to insure that the meaning was as similar as possible to the original. For the measurement of service recovery performance (SRPER) the scale developed by Boshoff and Allen's (2000) five items scale was employed: "Considering all the things I do, I handle dissatisfied customers quite well.", "I do not mind dealing with complaining customers.", "No customer I deal with leaves with problems unresolved.", "Satisfying complaining customers is a great thrill to me.", "Complaining customers I have dealt with in the past are among today's most loyal customers.”. For SRPER, the use of the self-report performance scale can be justified on the grounds that frontline employees are in the best position to evaluate their own performance outcomes (Bitner et al., 1994), and longitudinal research has established that their perceptions typically have a substantial overlap with those of the customers (Bernhardt et al., 2000). Moreover, affective organizational commitment, which was a study variable in the present investigation, was reported to be a better estimator of performance when the performance was measured by a self-rated measure (Riketta, 2002). Thus, measuring SRPER with a self-report measure was deemed acceptable, and the reliability of the composite scale as measured with Cronbach's alpha was .80.

For the purposes of the present study, extrinsic reward satisfaction (EXRES) was operationally defined as the extent to which rewards within the establishment were based on the individual performance and the satisfaction of the employee with the allocation of rewards. The three item scale, which was developed for the use in hospitality industry establishments was derived from Klidas et al. (2007), and included the statements of "The rewards I receive are determined according to my work", "The raises I receive depend on my effort" and "In this restaurant, the employees who reach high levels of attainment are systematically rewarded". The focus of this scale was satisfaction with extrinsic rewards obtained from individual gains and success from the eye of employee. The reliability of this composite scale as measured with Cronbach's alpha was .74. 
For measuring affective commitment (AFFCOM), the scale developed by Meyer et al. (1993) was employed. This scale was widely used in earlier studies in various work settings in Turkey, and the scale's original six-statement version was preferred. However, for the purposes of the study, words such as "organization" that appear in Meyer and colleagues' scale were replaced with "restaurant" or "firm" as appropriate. The reliability of this composite scale as measured with Cronbach's alpha was .65. Since reliability values over .60 mark were regarded generally acceptable (e.g., Suliman, 2001), it was concluded that this scale also showed an acceptable internal reliability.

\section{Control Variables}

The respondents' marital status, job tenure, and education level were employed as control variables. Gender was not included in this group of variables due to the male dominant nature of the profession, born out, first, by the rather low percent of women respondents in the sample (7.4\%), and, secondly, by a preliminary analysis of all study variables exhibiting no significant main effect on this variable (p>.05). Likewise, recent research on behavioral outcomes of frontline employees (Karatepe and Sökmen, 2006) showed that gender does not have a predictive power, whereas marital status can have a potential impact. Therefore, the marital status of the respondents was included in the control variables. As a potentially important indicator of both employee satisfaction and commitment, the respondents' job tenure was measured in months in order to account for the employment durations that were less or more than a full year in the same restaurant. However, age was not included in the list of control variables because it showed a high correlation with job tenure in the restaurant $(\mathrm{p}<.001)$, and if included, it could have posed the problem of multicollinearity. The descriptive statistics of the control variables employed in the study, as well as the dependent variable and the independent variables of the study are presented in Table 1 .

Table 1

Descriptive Statistics and Correlations of the Study Variables

\begin{tabular}{|c|c|c|c|c|c|c|c|c|c|}
\hline & Mean & SD & 1 & 2 & 3 & 4 & 5 & 6 & 7 \\
\hline 1. Marital St. ${ }^{1}$ & 1.45 & .50 & & & & & & & \\
\hline 2. Education ${ }^{2}$ & 10.47 & 2.89 & $-.159 *$ & & & & & & \\
\hline 3. Job Tenure ${ }^{3}$ & 41.66 & 41.10 & $.382 * *$ & -.130 & & & & & \\
\hline 4. AFFCOM & 4.07 & 0.99 & .114 & .113 & $.163^{*}$ & $(.65)$ & & & \\
\hline 5. EXRES & 3.61 & 1.49 & -.086 & $.250 * *$ & $-.157 *$ & $.329 * *$ & $(.74)$ & & \\
\hline 6. TISU & 4.38 & 098 & .010 & $.252 * *$ & .069 & $.461 * *$ & $.578^{* *}$ & $(.76)$ & \\
\hline 7. SRPER & 4.80 & 0.97 & .082 & .070 & .039 & $.391 * *$ & $.234 * *$ & $.354 * *$ & $(.80)$ \\
\hline
\end{tabular}

Notes: ${ }^{1}$ Marital Status $(1=$ Single, $2=$ Married $),{ }^{2}$ Education (in years). ${ }^{3}$ Job Tenure in the restaurant (in months). Diagonal provides Cronbach's Alpha reliability coefficients in parentheses for the composite scales. *Correlation is significant at the 0.05 level (2-tailed). ** Correlation is significant at the 0.01 level (2-tailed). 


\section{Test of the Hypotheses}

The hypotheses were tested with a series of regression analyses. The first step of the hierarchical regression included the relevant demographic variables as controls. At this phase, marital and job tenure were entered as dummy variables. The education level of the respondents was also treated as a categorical variable in the regression analyses. The hierarchical regression analysis revealed that none of the employed control variables had a significant predictive capacity for SRPER ( $p>.05)$. In the second step, the independent variables EXRES and AFFCOM were also entered into the hierarchical regression equation. In line with the first Hypothesis of the study, EXRES (Beta $=.223$, p<.01) was a significant predictor for SRPER, and thus it was concluded that the Hypothesis 1 was supported. As predicted in the second Hypothesis, AFFCOM was found also to have a significant effect (Beta = $.224, \mathrm{p}<.01)$. Generally speaking, these two variables were highly effective in employees' perception about their own performance $\left(\mathrm{R}^{2}=.160, \mathrm{p}<.001\right)$. As the final step, TISU was added to this regression to test the mediating role of this variable as predicted in Hypothesis 3 . The above outlined process was followed because, according to Baron and Kenny (1986), a mediation would be demonstrated when a) the independent variables and proposed mediator (TISU) had significant effects on the dependent variable (SRPER) when considered separately, b) the independent variables had an effect on the proposed mediator, and c) the independent variables' previously significant effects on the dependent variable would be reduced or disappear when the mediator was included in the model. The first and second columns in Table 2 present the results of the hierarchical regression analysis for the control variables, the independent variables of EXRES and AFFCOM as predictors of SRPER being the dependent variable of the investigation.

Table 2

\section{Results of Hierarchical Regression Analyses for Service Recovery Performance to Commitment, Satisfaction, and Trust $(\mathbf{N}=\mathbf{2 3 0})$}

\begin{tabular}{lccc}
\hline & Step 1 & Step 2 & Step 3 \\
\hline Independent Variables & & & \\
\hline Marital Status & $.124^{\mathrm{a}}$ & .091 & .092 \\
Job Tenure & .061 & .064 & .029 \\
Education & .136 & .045 & .003 \\
EXRES & & $.223^{*}$ & .083 \\
AFFCOM & & $.224^{*}$ & .142 \\
TISU & & & $.279^{*}$ \\
\hline & 1.72 & & \\
\hline Overall model F & .03 & $5.69 * *$ & $6.11^{* *}$ \\
Overall $R^{2}$ & .16 & .20 \\
\hline
\end{tabular}

Notes: ${ }^{\text {a }}$ Standardized regression coefficients are reported. Marital Status (dummy variable: $0=$ Single, $1=$ Married). Job Tenure in the restaurant (dummy variable determined by median split: $0=$ Low, $1=$ High). Education $(1=$ Primary, $2=$ Secondary, $3=$ High School, 4 = Vocational School, 5 = University).

The figures marked $(*)$ are significant at 0.01 and those marked $(* *)$ are significant at 0.001 levels. Durbin-Watson test score was 2.08 . VIF ranged between 1.1 and 2.1 for all variables that were included to the regression. 
This final step of the hierarchical regression indicated that when TISU was included to the equation, the previously significant contributions of EXRES and AFFCOM were now both diminished ( $\mathrm{p}>.05)$, and TISU showed a significant impact $($ Beta $=.279, \mathrm{p}<.01$ ), which demonstrated a strong support for full mediation in the regression analysis. Although the amount of change in $\mathrm{R}$ square was relatively small when TISU was included, this alteration was nevertheless significant ( $\breve{G} R^{2}=.038, p<.01$ ), and it has increased the total coefficient of determination to .20 after this step of the regression analysis ( $F$ $[6,148]=6.11, \mathrm{p}<.001)$. To determine whether these affective outcomes would be mediated by the employees' level of trust in the supervisor, as it was put forward in the Hypothesis 3, this relationship was tested by the mediation test. As a separate analysis, TISU was tested with a regression analysis to see if the control variables, EXRES and AFFCOM could be used to predict it. The results of this regression analysis showed that for the prediction of TISU, the employees' education (Beta $=.152$, $\mathrm{p}<.05)$ and tenure in the restaurant $($ Beta $=.123, \mathrm{p}<.05)$ had a moderate, whereas both EXRES (Beta $=.499, \mathrm{p}<.001)$ and AFFCOM $($ Beta $=.293, \mathrm{p}<.001)$ had a strong predictive capacity $\left(\mathrm{R}^{2}=.51\right.$, $\mathrm{p}<.001)$. This result was in line with Baron and Kenny's (1986) suggestion that for a mediation to exist, the independent variables should have strong main effect on the potential mediator $(\mathrm{F}[5,150]$ $=31.52, \mathrm{p}<.001)$. In other words, the analysis provided support for the Hypothesis 3 and revealed that in predicting SRPER, indeed TISU fully mediated both EXRES and AFFCOM. Taken together, the findings suggest that $20 \%$ of the observed variability in the frontline employees' self rated service recovery performance could be attributable to the affective facet of organizational commitment, to satisfaction with the provided extrinsic rewards, and especially to optimistic perceptions that their potential vulnerability would not be exploited by the immediate supervisor, i.e. the employees' trust in their supervisor.

\section{DICUSSION AND CONCLUSIONS}

Most researchers have contended that job attitudes of frontline employees are extremely important in securing customer satisfaction (e.g., Babakus et al., 2003; Hancer and George, 2003) and long term success was shown to be closely related to these attitudes as well (Bernhardt et al., 2000). The quality restaurant employees' on the job performance and its antecedents were at the heart of the present study. As suggested by Davis et al. (2000), this context provides a valuable opportunity to investigate the role of trust in the supervisor as a key variable. The restaurants are unique as they combine both manufacturing and sales under the same roof (Koutromanis, 2008), and their employees were the focus for two main reasons. First, these employees represent a sizable portion of the work force, which has so far not been studied extensively. According to the latest estimates, the grand total of waits-staff employed directly by restaurants in Turkey exceeds 400,000 people (Radikal, July 25, 2009) and thus the employment generation capacity of F\&B establishments could warrant a focus on this industry. Secondly, thought of in combination with the importance of boundary spanning roles for frontline employees from the service organizations' point of view (Babakus et al., 2002), and with securing customer satisfaction being more of a concern in quality restaurants (Davis, et al., 2003), it could be argued that the major work attitudes of the frontline personnel deserves special attention. Moreover, the results of this study could be helpful in elaborating strategies that may be employed to improve generalized trust in other business establishments.

The results support the notion that the trust in management needs to be taken into account as a key correlate for securing successful performance outcomes in the restaurant industry as concluded by Davis et al. (2000). Although both extrinsic reward satisfaction and affective commitment were found to be necessary as suggested by Babakus and colleagues (2002), the present findings showed that they 
were not sufficient by themselves to achieve a desired level of performance when not complemented by trust in the supervisor. Likewise the supervisor's perceived trustworthiness fully mediated the relationship between organizationally desirable performance, and its basic antecedents. In other words, without a solid belief in their supervisors' trustworthiness, the waits-staff was not willing to show an organizationally preferred amount of service recovery behavior. As this type of work outcome is regarded valuable in the context of quality restaurants, taking measures to further improve trust between employees and supervisors should not be considered an extravagance. In fact, the LMX theory also provides ground for this perspective since the theory posits that a supervisor - subordinate relationship could not extend outside the employment contract without the existence of mutual trust in the relationship (Brower et al., 2000).

Trust in the supervisor could be regarded as especially consequential in achieving employee involvement, which was regarded to be an important precursor to work effort. To achieve this end, the human resource (HR) function should be given a special emphasis, because the way "frontline workers gather, process, and act on information is key to the successful link between HR systems and performance" (Tracey et al., 2008: 12). Organizations in general can use intervening practices for increasing participation in decision-making and opportunities for voice. Securing constant feedback to employees and providing room for employee empowerment within the organizational framework (Nyhan, 1999; Koutromanis, 2008) should be considered primary. Therefore, recommendations to increase the strength of the bond between supervisor and subordinate can be said to be well grounded. In enhancing trust among workers through such practices, managers can further widen the communication channels so that both the employee and the organization will benefit from this exchange. In its most basic terms trust in the supervisor could only be expected to rise when the employees foster perceptions about being fairly treated and rewarded. However, trust within enterprises should not be expected to pivot with a few HR measures in the short run, because trust often develops in an upward spiral which can easily drop to lower levels. Thus, attaining trust in the supervisor should be ingrained in the philosophy of the companies that would like to reap the long term benefits.

Some authors (e.g., Severt and Curtis, 2008) contend that securing participation of employees in various fashions is the key variable for trust building and for developing a service culture which is directed toward minimizing internal service failures. The present study findings provided empirical support for the proposition of Severt and Curtis (2008: 122) that when frontline employees felt supported and that they could trust the management, they “... transfer those perceptions back to the entire organization through interactions with other employees and ... with customers". For achieving such a service culture, the following qualities could be deemed essential: augmentation of support by executives in a work environment in which employees feel a mutual commitment, and confidence by the employees that their supervisors will value their contributions and reinforce their performance. Indeed, participative management was found to have positive effects on performance as well as on productivity, affective commitment and job satisfaction (Nyhan, 1999). Based on the findings of the study that the control variables have no particular effect on the investigated network of variables, it could also be suggested that attempts to expand the circle of trust within quality restaurants and in similar work settings regardless of demographic variables like marital status, tenure in the firm, and education level of the personnel, could provide evidence that this strategy could be an efficient one. The results about demographic variables were also in line with a recent meta-analysis on affective commitment - performance link, where Riketta (2002) found that demographic characteristics like age, job level and tenure did not predict the relationship between affective commitment and performance. 
Different forms of participative leadership including the perception by employees that their contributions are valued often result in the employees assuming a certain level of ownership of their work and an increased commitment to the firm. These outcomes could be suggested to be the results of three basic human needs: sensations of increased autonomy, increased meaningfulness and decreased isolation. Thus, the supervisors' task should be to send clear signs that they have confidence in the abilities of their employees that their contribution to the firm is appreciated and would be supported when they have to face circumstances that demand such support. Recently, Huang et al. (2010) demonstrated that the participative leadership and performance link is mediated by trust in the supervisor in nonmanagerial employees, whereas psychological empowerment has replaced it in the case of middle managers. It could be suggested that the respondents in the present study, who believed that they had trustworthy supervisors, felt uninhibited in acting upon service failure situations to bring the situation back in balance in terms of customer satisfaction. As the perceived trust in their supervisor increased, the non-managerial employees felt more relaxed in using their autonomy to take action. Therefore, some suggestions to strengthen this link could include building strong bonds between the supervisors and the employees through a bottom-up approach, securing the flow of feed back to and from the employees, making opportunities to contribute to decision making in the organization, and encouraging more assumption of responsibility in accomplishing the work. The repercussions of the study findings provided support for the proposition that the affective employee attitudes and extrinsic reward satisfaction factors in isolation may not be good enough to achieve the desired level of performance, especially without the existence of a reasonably high employee confidence in their immediate managers in the quality restaurants. In other words, as it is the case in almost all facets of life, to trust or not to trust is also the question in most business settings.

\section{LIMITATIONS AND FUTURE RESEARCH IMPLICATIONS}

Several limitations are inherent in this study, and thus these should be taken into account while interpreting the findings. First, the results here were based on data that was collected from quality restaurant wait-staff only, whose work requires conducting the duties in relatively flexible work arrangements and in small teams. This sample selection may lead to generalizability problems in applying the findings to employees working on inflexible work schedules, for example. Moreover, because of the cross-sectional time horizon of the study, it was impossible to establish causality. On the other hand, the facts that the data was collected from a moderately large group of respondents and that there was some level of randomization in the sampling, provide an indication that these limitations may not be a serious concern. For future research, structural equation modeling could help to alleviate this problem with larger and longitudinal data sets. Secondly, in terms of the measurement of the study variables, the self-report nature of the collected data could raise concerns about common method bias. However, as discussed earlier, since the respondents were thought to be in the best position to evaluate their performance outcomes, their individual assessments were not expected to seriously contaminate the present findings. One point that needs attention about measurement of study variables is that the employed affective commitment scale has demonstrated a slightly low internal reliability level in this sample. Nevertheless, this scale's reliability was above the bare minimum mark determined in the literature, as discussed earlier.

Furthermore, some researchers (e.g., Aryee et al., 2002; Tan and Tan, 2000) contended that trust within organizations could be viewed from two different perspectives: the employees' trust in organization, and their trust in the supervisor. Although for the purposes of this investigation, the data collection 
was restricted to trust in the supervisor, a fuller understanding in terms of generalized trust within organizations would require the investigation of the other two dimensions of generalized trust, and future research may include both of these dimensions. Moreover, impacts of participative leadership on performance mediated by trust in the supervisor and job satisfaction investigated comparatively on managerial and non-managerial employees may provide clearer ground for understanding the differences caused by job type. Finally, it should also be stated that the present investigation did not explore reciprocity in trusting relationships between leader and subordinate. Expanding this line of research by including the supervisors' perspective, i.e., trust in the subordinate, could provide a fruitful venue for investigation.

\section{REFERENCES}

Agho, A.O., Mueller, C.W., and Price, J.L. (1993). "Determinants of Employee Job Satisfaction: An Empirical Test of a Causal Model," Human Relations, 46(8): 1007-1027.

Severt, D.E. and Curtis, C. (2008). "Human Resources Management and a Service Culture," in D.V. Tesone (ed.), Handbook of Hospitality Human Resources Management: 115-133. Oxford: Elsevier.

Allen, N.J. and Meyer, J.P. (1990). "The Measurement and Antecedents of Affective, Continuance and Normative Commitment to the Organization," Journal of Occupational Psychology, 1: 61-89.

Aryee, S., Budhwar, P.S., and Chen, Z.X. (2002). "Trust as a Mediator of Relationship between Organizational Justice and Work Outcomes: Test of a Social Exchange Model," Journal of Organizational Behavior, 23: 267-285.

Arnett, D.B., Laverie, D.A., and McLane C. (2002). "Using Job Satisfaction and Pride as Internalmarketing Tools," Cornell Hotel and Restaurant Administration Quarterly, 42(2): 87-96.

Baba, V.V., Tourigny, L., Wang, X., and Liu, W. (2009). "Proactive Personality and Work Performance in China: The Moderating Effects of Emotional Exhaustion and Perceived Safety Climate," Canadian Journal of Administrative Sciences, 26: 23-37.

Babakus, E., Yavas, U., Karatepe, O.M., and Avc1, T. (2003). “The Effect of Management Commitment to Service Quality on Employees' Affective and Performance Outcomes," Journal of the Academy of Marketing Science, 31(3): 272-286.

Baron, R. and Kenny, D. (1986). “The Moderator-Mediator Variable Distinction in Social Psychology Research," Journal of Personality and Social Psychology, 51: 1173-1182.

Bennett, N., Carson, P.P., Carson, K.D., Phillips P., and Blum, T.C. (1994) "A Comparison of 'Traditional' and 'Atypical' Workers: Demographic, Behavioral, and Attitudinal Differences," Journal of Business and Psychology, 8(4): 467-474.

Bernhardt, K.L., Donthu, N., and Kennett, P.A. (2000). “A Longitudinal Analysis of Satisfaction and Profitability," Journal of Business Research, 47: 161-171. 
Boshoff, C. and Allen, J. (2000). "The Influence of Selected Antecedents of Frontline Staff's Perceptions of Service Recovery Performance," International Journal of Service Industry Management, 11(1): 63-90.

Brower, H.H., Schoorman, F. D., and Tan, H.H. (2000). “A Model of Relational Leadership: The Integration of Trust and Leader-Member Exchange," Leadership Quarterly, 11(2): 227-250.

Chen, Y.J. (2007). "Relationship among Service Orientation, Job Satisfaction, and Organizational Commitment in the International Tourist Hotel Industry," The Journal of American Academy of Business, 11(2): 71-82.

Cho, S., Johanson, M.M., and Guchait, P. (2009). "Employees' Intent to Leave: A Comparison of Determinants of Intent to Leave Versus Intent to Stay." International Journal of Hospitality Management, 28: 374-381.

Davis, B., Lockwood, A., and Stone, S. (2003). Food and Beverage Management. Oxford: Elsevier.

Davis, J.H., Schoorman, F.D., Mayer, R.C., and Tan, H.H. (2000). "The Trusted Manager and Business Unit Performance: Empirical Evidence of a Competitive Advantage," Strategic Management Journal, 21: 563-576.

Ertürk, A. and Ceylan, A. (2002). "The Relationship between Intrinsic Motivation and Organizational Commitment: An Empirical Study on the Private Sector,” Boğaziçi Journal, 16(2): 73-87.

Goris, J.R., Vaught, B.C., and Pettit, J.D. (2003). "Effects of Trust in Supervisors and Influence of Supervisors on the Association between Individual-Job Congruence and Job Performance/ Satisfaction," Journal of Business and Psychology, 17(3): 327-343.

Göncü, A. (2006). Motivational Processes Involved in the Relationship between Leadership and Organizational Citizenship Behaviors. Istanbul: Unpublished master's thesis, Koç University.

Hancer, M. and George, R.T. (2003). "Job Satisfaction of Restaurant Employees: An Empirical Investigation Using the Minnesota Satisfaction Questionnaire," Journal of Hospitality and Tourism Research, 27(1): 85-100.

Hofstede, G. (2006). "Cultural Constraints in Management Theories," in J.S. Osland, M.E. Turner, D.A. Kolb and I.M. Rubin (eds.), The Organizational Behavior Reader, 25-38.

Hosmer, L.T. (1995). “Trust: The Connecting Link between Organizational Theory and Philosophical Ethics," Academy of Management Review, 20: 379-403.

Huang, X., and Van de Vliert, E. (2003). "Where Intrinsic Motivation Fails to Work: National Moderators of Intrinsic Motivation," Journal of Organizational Behavior, 24: 159-179.

Huang, X., Iun, J., Liu, A., and Gong, Y. (2010). "Does Participative Leadership Enhance Work Performance by Inducing Empowerment and Trust? The Differential Effects on Managerial and NonManagerial Subordinates," Journal of Organizational Behavior, 31: 122-143. 
Inelmen, K. (2006). "Subordinates' Trust toward Their Supervisors in High-End Hotels," in S. Stashevsky (ed.), Work Values and Behavior, Proceedings of the 10 $0^{\text {th }}$ ISSWOV Conference: 145-151.

İşbaşı, J.Ö. (2001). “Çalışanların Yöneticilerine Duydukları Güvenin ve Örgütsel Adalete İlişkin Algılamalarının Vatandaşlık Davranışının Oluşumundaki Rolü (Shaping the Role of Trust in Supervisor and Organizational Justice Perceptions on Organizational Citizenship Behavior), “Yönetim Araştırmaları Dergisi, October, 1: 51-73.

Karatepe, O. and Sökmen, A. (2006). "The Effects of Work Role and Family Role Variables on Psychological and Behavioural Outcomes of Frontline Employees," Tourism Management, 27: 255268.

Klidas, A., van den Berg, P.T., and Wilderom, C.P.M. (2007). "Managing Employee Empowerment in Luxury Hotels in Europe," International Journal of Service Industry Management, 18(1): 70-88.

Koutromanis, D.A. (2008). "Organizational Culture in the Casual Dining Restaurant Industry," in D.V. Tesone (ed.), Handbook of Hospitality Human Resources Management: 63-82. Oxford: Elsevier.

Lawler, E.E. III (2005). "Creating High Performance Organizations,” Asia Pacific Journal of Human Resources, 43: 10-17.

Mathieu, I. and Zajac, D. (1990). "A Review and Meta-Analysis of Antecedents, Correlates and Consequences of Organizational Commitment," Psychological Bulletin, 108: 171-194.

Mayer, R.C., Davis, J.H., and Schoorman, F.D. (1995). “An Integrative Model of Organizational Trust," Academy of Management Review, 20: 709-734.

Meyer, J.P. and Allen, N.J. (1991). “A Three-Component Conceptualization of Organizational Commitment," Human Resource Management Review, 1: 61-89.

Meyer, J.P., Stanley, D.J., Herscovitch, L., and Topolnytsky, L. (2001). “Affective, Continuance and Normative Commitment to the Organization: A Meta-Analysis of Antecedents, Correlates, and Consequences," Journal of Vocational Behavior, 61: 20-52.

Mowday, R.T., Porter, L.W., and Steers, R.M. (1982). Employee Organization Linkages: The Psychology of Commitment, Absenteeism and Turnover. New York: Academic Press.

Nyhan, R.C. (1999). "Increasing Affective Commitment in Public Organizations," Review of Public Personnel Administration, (Summer 1999): 58-70.

Radikal (July 25, 2009) “400 bin Kişiye İstihdam (Employment for 400,000 people)”: 9.

Riketta, M. (2002). “Attitudinal Organizational Commitment and Job Performance: A Meta-Analysis," Journal of Organizational Behavior, 23: 257-266. 
Rousseau, D.M., Sitkin, S.B., Burt, R.S., and Camerer, C. (1998). "Not So Different After All: A Cross-Discipline View of Trust," The Academy of Management Review, 23(3): 513-530.

Siders, M.A., George, G., and Dwarwadkar, R. (2001). "The Relationship of Internal and External Commitment Foci to Objective Job Performance Measures,” Academy of Management Journal, 44(3): $570-579$.

Suliman, A.M.T.(2001). "Work Performance: Is It One Thing or Many Things? The Multidimensionality of Performance in the Middle Eastern Context," International Journal of Human Resource Management, 12(6): 1049-1061.

Tan, H.H. and Tan, C.S. (2000). "Toward a Differentiation of Trust in Supervisor and Trust in Organization," Genetic, Social, and General Psychology Monographs, 126(2): 241-260.

Tax, S.S., Brown, S.W., and Chandrashekaran, M. (1998). "Customer Evaluations of Service Complaint Experiences: Implications for Relationship Marketing," Journal of Marketing, 62: 60-76.

Tracey, J.B., Way, S.A., and Tews, M.J. (2008). "HR in the Hospitality Industry: Strategic Frameworks and Priorities," in D.V. Tesone (ed.), Handbook of Hospitality Human Resources Management: 3-22. Oxford: Elsevier.

Wasti, S.A. (2003). "The Influence of Cultural Values on Antecedents of Organizational Commitment: An Individual-Level Analysis," Applied Psychology: An International Review, 52: 533-554.

Whitener, E.M., Brodt, S.E., Korsgaard, M.A., and Werner, J.M. (1998). "Managers as Initiators of Trust: An Exchange Relationship Framework for Understanding Managerial Trustworthy Behavior," The Academy of Management Review, 23(3): 513-530.

Wu, C.H. and Liang, R. (2009). "Effect of Experiential Value on Customer Satisfaction with Service Encounters in Luxury-Hotel Restaurants," International Journal of Hospitality Management, 28: 586593.

Zeytinoğlu, I.U., Denton, M., Davies, S., Baumann, A., Blyte, J., and Boos, L. (2006). "Retaining Nurses in their Hospitals and in the Profession: Effects of Job Preference, Unpaid Overtime, Importance of Earnings and Stress," Health Policy, 79: 57-72. 


\section{APPENDIX A.}

‘Trust in Supervisor' Scale

1. I know that my supervisor would reward me when I do something successful.

2. I believe that my supervisor evaluates me only with my job performance.

3. I have confidence that my supervisor would protect me when I am right.

4. I believe that my supervisor deserves his/her position.

5. There are some job related matters which I would rather consult with my supervisor's manager. (R)

6. What my supervisor say and does, totally overlaps.

7. I feel uneasy with my supervisor's authority. (R)

8. I have confidence in my supervisor's requests and suggestions. 